\title{
INTRAPOPULATIONAL GENETIC DIFFERENTIATION IN Anopheles (N.) darlingi ROOT, 1926 (DIPTERA: CULICIDAE) IN THE AMAZON REGION
}

\author{
Joselita Maria Mendes dos Santos ${ }^{1}$, Jorge Arturo Lobo ${ }^{2}$, Wanderli Pedro Tadei ${ }^{1}$ and Eucleia P. Betioli Contel ${ }^{3}$
}

\begin{abstract}
Four natural Amazonian Anopheles darlingi populations were analyzed for 19 loci, 12 of which showed variation, i.e., $68.4 \%$ of polymorphic loci. The Ariquemes, Rondônia, population was the most variable, with a large number of alleles per locus (2.26 $\pm 0.27)$ and high polymorphism $(P=63.15)$. The highest values of observed and expected intralocus heterozygosity were observed in the Manaus, Amazonas, population ( $\mathrm{Ho}=0.432 \pm 0.11$; $\mathrm{He}=0.375 \pm 0.08$ ), and the lowest in the Cachoeira Porteira, Pará, population ( $\mathrm{Ho}=0.236 \pm 0.09 ; \mathrm{He}=0.290 \pm 0.11)$. Wright's F-statistic revealed disequilibrium caused by an excess of homozygotes, as shown by the $F_{\text {is }}>F_{\text {st }}$ values $\left(F_{i s}=0.083>0.026\right)$ reflecting intrapopulational differentiation. The four populations studied were genetically similar, as indicated by distance and similarity values. Chromosomal variation of Amazon population also did not indicate geographical differentiation, and populations in the central region of the Amazon Basin showed high polymorphism in relation to the marginal populations, which were mainly monomorphic.
\end{abstract}

\section{INTRODUCTION}

An increasing number of studies on biological and genetical variability of Anopheles darlingi have been published in the last few years due to the importance of this mosquito as the major vector of human malaria in Brazil, especially in the Amazon region. These studies have demonstrated plasticity in response to environmental changes, which might affect the transmission of this disease (Santos et al., 1981, 1985; Tadei and Santos, 1982; Tadei et al., 1982; Rosa-Freitas et al., 1992, 1995; Harbach et al., 1993).

Chromosome polymorphism studies have revealed significant genetic differentiation between populations of A. darlingi from northern and southern Brazil. High frequencies of inversion in heterozygotes were observed in populations from the Amazon region (Kreutzer et al., 1972; Tadei and Santos, 1982; Tadei et al., 1982).

Brazilian populations of $A$. darlingi revealed specific differences in hydrocarbon profiles from Ilha de Maracá, State of Roraima, and Jaru, State of Rondônia (Walsh, 1989, in Rosa-Freitas et al., 1995). Distinctive hydrocarbon patterns in this species were also found by Rosa-Freitas et al. (1992) in Dourado (São Paulo) and Costa Marques (Rondônia), although specimens from Juturnaíba were often misassigned. However, these authors did not find significant behavior or allozyme differences in these populations.

Mitochondrial DNA and morphological studies were carried out for six Brazilian populations of $A$. darlingi (Juturnaíba, Dourado, Costa Marques, Cuiabá, Manaus,

${ }^{1}$ Coordenação de Pesquisas em Ciências da Saúde, INPA, Alameda Cosme Ferreira, 1756, 69011-970 Manaus, AM, Brasil. Send correspondence to J.M.M.S.

${ }^{2}$ Escuela de Biologia, Universidad da Costa Rica, San José, Costa Rica. ${ }^{3}$ Departamento de Genética, Faculdade de Medicina de Ribeirão Preto, 14049-900 Ribeirão Preto, SP, Brasil. and Capanema), but none showed morphological differences, and nucleotide divergence estimates were not high (Rosa-Freitas et al., 1995).

In the present study, four populations of $A$. darlingi were analyzed using enzymatic variation of 19 loci to understand the genetic structure of this species, which is the principal vector of human malaria in the Brazilian Amazon.

\section{MATERIAL AND METHODS}

Mosquitoes were obtained from natural populations from four locations in the Amazon region: Ariquemes $\left(10^{\circ}\right.$ $\left.\mathrm{S}, 63^{\circ} \mathrm{W}\right)$ and Porto Velho/Samuel $\left(9^{\circ} \mathrm{S}, 63^{\circ} \mathrm{W}\right)$, State of Rondônia; Manaus $\left(3^{\circ} \mathrm{S}, 60^{\circ} \mathrm{W}\right)$, State of Amazonas, and Cachoeira Porteira $\left(1^{\circ} \mathrm{S}, 57^{\circ} \mathrm{W}\right)$, State of Pará (Figure 1).

Wild females laid eggs individually in the laboratory, and from each single brood an average of five individuals were used for each single enzymatic system (Table I). Electrophoretic techniques and enzyme recipes were those described in Steiner and Joslyn (1979) and Lima and Contel (1990). The gels were prepared as described by Santos et al. (1996). The following loci were analyzed: EST1, EST2, EST5, LAP1, LAP2, LAP5, IDH1, IDH2, ODH1, ODH2, ODH3, AO1, AO2, XDH1, GDH, G-6PDH, 6-PGDH, $\alpha-G P D H$ and $P G M$.

Allele frequencies were estimated directly from the data. In the case of null alleles, their frequencies were estimated by maximum likelihood, using the dominance model of inheritance. Proportion of polymorphic loci (P), heterozigosities and Wright's F-coefficients were estimated using the Biosys Program (Swofford and Selander, 1981). The fixation index within populations $\left(\mathrm{F}_{\mathrm{is}}\right)$ was also calculated using ALPHA software of the Genioc Program collection (Cabello and Krieger, 1997), with option 4 (calculation of $\mathrm{F}$ between systems). A dendrogram was constructed using the UPGMA method (Nei, 1978). 


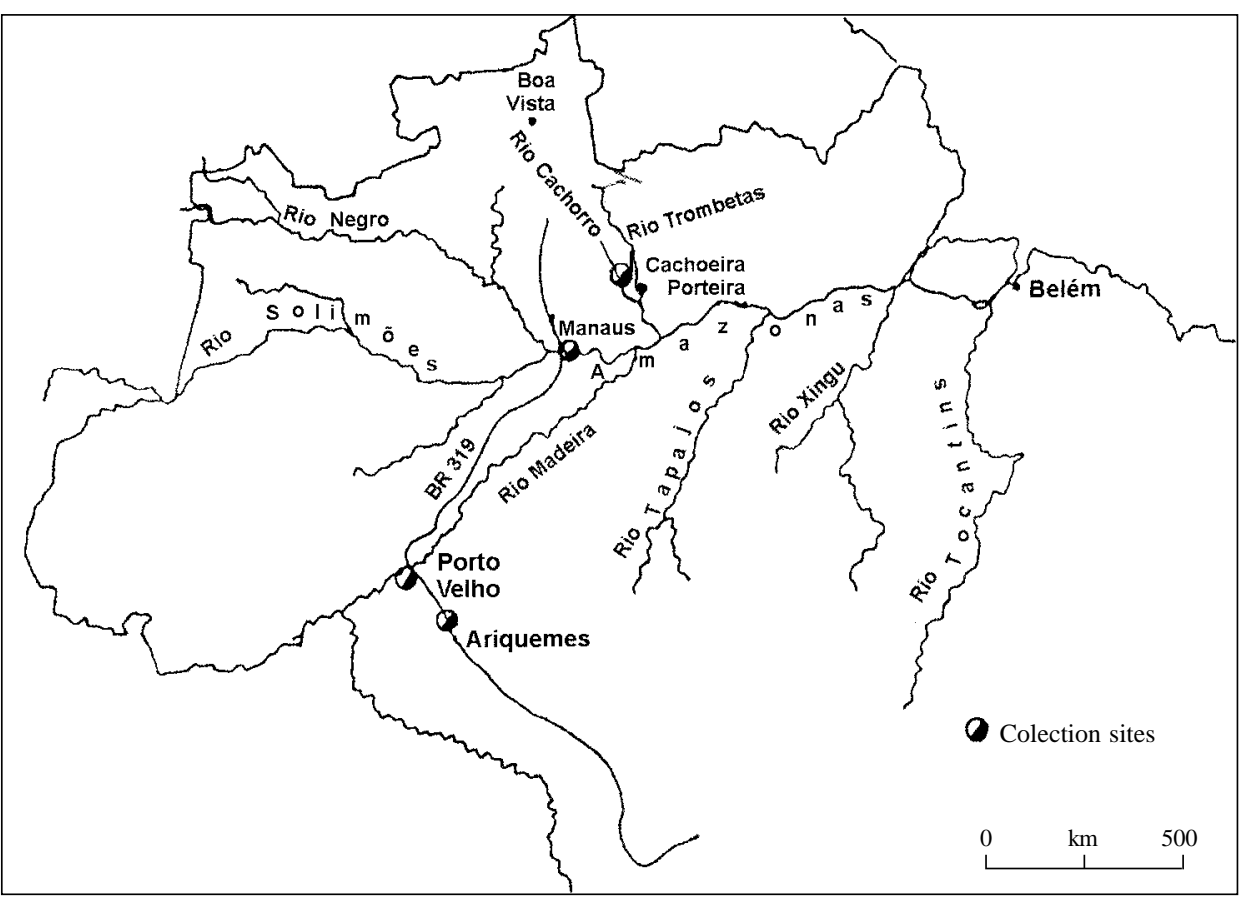

Figure 1 - Collection sites of Anopheles darlingi populations in the Amazon region.

Table I - Gene frequencies of alleles at each locus of the Anopheles darlingi populations analyzed. $(\mathrm{N})=$ Sample size; $\mathrm{O}=$ null allele; $\mathrm{nc}=$ frequency not calculated; - = inexistent allele $;{ }^{1}=$ rare $\mathrm{PGM}$ alleles.

\begin{tabular}{|c|c|c|c|c|c|}
\hline \multirow[b]{2}{*}{ Locus } & \multirow[b]{2}{*}{ Allele } & \multicolumn{4}{|c|}{ Population } \\
\hline & & Ariquemes & $\begin{array}{l}\text { Porto Velho / } \\
\text { Samuel }\end{array}$ & $\begin{array}{l}\text { Cachoeira } \\
\text { Porteira }\end{array}$ & Manaus \\
\hline \multirow[t]{3}{*}{ EST2 } & $(\mathrm{N})$ & 273 & 223 & 236 & 56 \\
\hline & $\mathrm{F}$ & 0.468 & 0.363 & 0.460 & 0.518 \\
\hline & $\mathrm{S}$ & 0.532 & 0.637 & 0.540 & 0.482 \\
\hline \multirow[t]{5}{*}{ EST5 } & $(\mathrm{N})$ & 397 & 209 & 198 & 41 \\
\hline & A & 0.307 & 0.218 & 0.291 & 0.341 \\
\hline & B & 0.227 & 0.409 & 0.376 & 0.427 \\
\hline & $\mathrm{C}$ & 0.260 & 0.249 & 0.151 & 0.146 \\
\hline & D & 0.206 & 0.124 & 0.182 & 0.086 \\
\hline \multirow{4}{*}{$I D H 1$} & $(\mathrm{~N})$ & 145 & 299 & 76 & 106 \\
\hline & A & 0.024 & - & 0.020 & 0.108 \\
\hline & B & 0.952 & 0.930 & 0.908 & 0.741 \\
\hline & $\mathrm{C}$ & 0.024 & 0.070 & 0.072 & 0.151 \\
\hline \multirow{7}{*}{$O D H 1$} & $(\mathrm{~N})$ & 133 & 119 & 136 & 106 \\
\hline & F & 0.135 & 0.155 & - & 0.146 \\
\hline & $\mathrm{S}$ & 0.865 & 0.845 & 1.000 & 0.854 \\
\hline & $(\mathrm{N})$ & 0 & 126 & 0 & 0 \\
\hline & $\mathrm{F}$ & $\mathrm{nc}$ & 0.125 & $\mathrm{nc}$ & $\mathrm{nc}$ \\
\hline & S & $\mathrm{nc}$ & 0.657 & $\mathrm{nc}$ & $\mathrm{nc}$ \\
\hline & $\mathrm{O}$ & $\mathrm{nc}$ & 0.218 & $\mathrm{nc}$ & $\mathrm{nc}$ \\
\hline \multirow[t]{3}{*}{$A O 1$} & $(\mathrm{~N})$ & 130 & 135 & 131 & 98 \\
\hline & $\mathrm{F}$ & 0.977 & 0.978 & 1.000 & 1.000 \\
\hline & $\mathrm{S}$ & 0.023 & 0.022 & - & - \\
\hline \multirow{6}{*}{$P G M$} & $(\mathrm{~N})$ & 156 & 119 & 84 & 101 \\
\hline & A & 0.170 & 0.134 & 0.179 & 0.074 \\
\hline & B & 0.647 & 0.702 & 0.780 & 0.861 \\
\hline & C & 0.048 & 0.164 & 0.042 & 0.064 \\
\hline & $\mathrm{A}^{1}$ & 0.042 & - & - & - \\
\hline & $\mathrm{B}^{1}$ & 0.093 & - & - & - \\
\hline \multirow{2}{*}{\multicolumn{2}{|c|}{$\begin{array}{l}\text { No. of alleles/locus } \\
\% \text { Polymorphic loci }\end{array}$}} & $2.26 \pm 0.27$ & $2.05 \pm 0.23$ & $1.94 \pm 0.23$ & $1.89 \pm 0.22$ \\
\hline & & 63.15 & 57.89 & 52.63 & 52.63 \\
\hline
\end{tabular}




\section{RESULTS}

\section{Allelic frequencies and polymorphism}

Twelve of the 19 loci studied presented genetic variability in the four populations: EST1, EST2, EST5, LAP5, IDH1, ODH1, ODH2,ODH3, AO1, AO2, $\alpha-P G D H$, and $P G M$. LAP1, LAP2, IDH2, XDH1, GDH, G-6PDH and 6$P G D H$ were monomorphic in all populations. The locus 6$P G D H$ showed variation only in the Ariquemes population.

Table I shows the number of alleles per locus in each of the four populations. The Ariquemes population was the most polymorphic and presented the largest number of alleles per locus. The Manaus and Cachoeira Porteira populations showed the lowest degree of polymorphism and the lowest number of alleles per locus.

\section{Hardy-Weinberg equilibrium}

Most of the loci analyzed in the Ariquemes and Manaus populations were not in Hardy-Weinberg equilibrium (Table II). Porto Velho/Samuel and Cachoeira Porteira population loci were found to be in equilibrium, except for EST2 in the latter and IDH1 in both. However, EST2 homozygotes from the same population were more frequent than expected $(E S T 2 * F / E S T 2 * F$ and $E S T 2 * S /$ $E S T 2 * S$ genotypes). The same was observed in Ariquemes, where homozygote classes for the same locus (EST2) presented significantly higher values than heterozygotes, and this pattern (excess of homozygotes) was not observed for all loci for which chi-square values were significant. In the Manaus population, the heterozygote class was the most frequent for the EST2 locus.

\section{Estimate of heterozygosity and $F$ coefficient of Wright}

Levels of observed and expected intralocus heterozygosity varied within each population (Table III). The
Manaus population showed the highest level of heterozygosity. This result contrasts with those obtained for number of alleles per locus and percentage of polymorphic loci, for which Manaus presented the lowest variability. The Porto Velho/Samuel population presented a wide range of observed heterozygosity and an amplitude of expected heterozygosity. Most of the loci analyzed also had excess homozygotes, with highly significant $\mathrm{F}$ values at the $1 \%$ level for loci EST2.

Despite the excess homozygotes observed in most of the loci analyzed, we also detected excess heterozygotes for locus EST5 in Ariquemes, $O D H 1$ in Porto Velho/ Samuel and EST2, IDHI and PGM in Manaus. Of these, only EST2 in Manaus and EST5 in Ariquemes showed statistically significant $(\mathrm{P}<0.05)$ excess heterozygosity.

The total $\mathrm{F}$ calculated by maximum likelihood (Table III) shows that there was significant disequilibrium in favor of excess homozygosity in the Ariquemes, Porto Velho/Samuel and Cachoeira Porteira populations. The mean $\mathrm{F}$ for Manaus was $0.01 \pm 0.03$, which does not differ significantly from zero. However, the standard error for the $\mathrm{F}$ estimates in the other populations ranged from 0.02 to 0.03 , being much lower than the mean estimated values. The F coefficient was higher in Cachoeira Porteira and lower in Porto Velho/Samuel, possibly due to the influence of EST2 locus which did not show disequilibrium in Porto Velho/Samuel.

However, as can be seen from the values for each locus, mean $\mathrm{F}$ was significantly different between systems of the Ariquemes and Cachoeira Porteira populations, precisely those with the highest $F$ values. This result was obtained from the chi-square values for heterogeneity (Table III).

\section{Population genetic structure}

$\mathrm{F}_{\text {is }}$ and $\mathrm{F}_{\mathrm{st}}$ values varied considerably from locus to locus. $F_{\text {is }}$ values were greater than $\mathrm{F}_{\mathrm{st}}$ values for almost all loci, with the exception of EST5 and IDHI (Table IV).

Table II - Chi-square values observed in test of Hardy-Weinberg equilibrium for five polymorphic loci in natural populations of Anopheles darlingi.

\begin{tabular}{|lccccc|}
\hline & & \multicolumn{4}{c|}{ Population } \\
\cline { 3 - 6 } Locus & $\begin{array}{c}\text { Number of } \\
\text { phenotypes }\end{array}$ & Ariquemes & $\begin{array}{c}\text { Porto Velho/ } \\
\text { Samuel }\end{array}$ & $\begin{array}{c}\text { Cachoeira } \\
\text { Porteira }\end{array}$ & Manaus \\
\hline EST2 & 3 & $68.25(1)^{* *}$ & $0.55(1)$ & $46.85(1)^{* *}$ & $18.41(1)^{* *}$ \\
EST5 & 10 & $84.57(6)^{* *}$ & $8.08(6)$ & $6.13(6)$ & $14.21\left(4^{+}\right)^{*}$ \\
& & $10.61(3)^{*}$ & $23.94(1)^{* *}$ & $16.28(3)^{* *}$ & $5.24(3)^{\mathrm{a}}$ \\
IDH1 & 6 & $1.43(1)^{\mathrm{b}}$ & & $3.45(1)^{\mathrm{b}}$ & $4.36(1)^{* \mathrm{~b}}$ \\
& 3 & $3.25(1)$ & $0.83(1)$ & - & $4.52(1)^{*}$ \\
ODH1 & 15 & $102.97\left(8^{+}\right)^{* *}$ & $5.50(3)$ & $7.04(3)$ & $5.81(3)$ \\
PGM & 15 & $44.87(3)^{* * \mathrm{c}}$ & $2.23(1)^{\mathrm{b}}$ & $0.34(1)^{\mathrm{b}}$ & $0.77(1)^{\mathrm{b}}$ \\
\hline
\end{tabular}

${ }^{+}=$Class comprising all the phenotypes that were not observed; ${ }^{a}=$ Alleles grouped $(C+D) ;{ }^{b}=$ Alleles grouped $(\mathrm{A}+\mathrm{C}) ;{ }^{\mathrm{c}}=$ Alleles grouped $\left(\mathrm{A}^{1}+\mathrm{B}^{1}+\mathrm{C}\right) .-=\chi^{2}$ was not calculated. $(\mathrm{i})=$ d.f. $=$ the number within parentheses. $* \mathrm{P}<0.05 ; * * \mathrm{P}<0.01$. 
Table III - Observed (Ho) and expected (He) heterozygosity and respective Wright Fvalue for each locus in the Anopheles darlingi populations analyzed.

\begin{tabular}{|c|c|c|c|c|c|}
\hline \multirow[b]{2}{*}{ Locus } & & \multicolumn{4}{|c|}{ Population } \\
\hline & & Ariquemes & $\begin{array}{c}\text { Porto Velho/ } \\
\text { Samuel }\end{array}$ & $\begin{array}{c}\text { Cachoeira } \\
\text { Porteira }\end{array}$ & Manaus \\
\hline \multirow[t]{3}{*}{ EST2 } & Но & 0.249 & 0.439 & 0.275 & 0.785 \\
\hline & $\mathrm{He}$ & 0.497 & 0.462 & 0.496 & 0.499 \\
\hline & $\mathrm{F}$ & $0.499 * *$ & 0.049 & $0.445 * *$ & $-0.573 * *$ \\
\hline \multirow[t]{3}{*}{ EST5 } & Ho & 0.778 & 0.665 & 0.666 & 0.634 \\
\hline & $\mathrm{He}$ & 0.744 & 0.707 & 0.717 & 0.671 \\
\hline & $\mathrm{F}$ & $-0.045^{* *}$ & 0.059 & 0.071 & 0.056 \\
\hline \multirow[t]{3}{*}{ IDHI } & Ho & 0.082 & 0.093 & 0.157 & 0.490 \\
\hline & $\mathrm{He}$ & 0.093 & 0.130 & 0.169 & 0.416 \\
\hline & $\mathrm{F}$ & 0.110 & $0.284 * *$ & 0.070 & $-0.175^{*}$ \\
\hline \multirow[t]{3}{*}{ ODH1 } & Ho & 0.270 & 0.182 & 0.000 & 0.198 \\
\hline & $\mathrm{He}$ & 0.233 & 0.164 & 0.000 & 0.249 \\
\hline & $\mathrm{F}$ & -0.156 & -0.109 & - & $0.207 *$ \\
\hline \multirow[t]{3}{*}{ AO1 } & Ho & 0.015 & 0.014 & 0.000 & 0.000 \\
\hline & $\mathrm{He}$ & 0.044 & 0.042 & 0.000 & 0.000 \\
\hline & $\mathrm{F}$ & 0.659 & 0.666 & - & - \\
\hline \multirow[t]{3}{*}{$P G M$} & Ho & 0.397 & 0.394 & 0.321 & 0.490 \\
\hline & $\mathrm{He}$ & 0.539 & 0.462 & 0.358 & 0.416 \\
\hline & $\mathrm{F}$ & $0.263^{* *}$ & 0.146 & 0.103 & -0.177 \\
\hline \multirow[t]{4}{*}{ Total } & Ho & $0.298 \pm 0.11$ & $0.297 \pm 0.09$ & $0.236 \pm 0.09$ & $0.432 \pm 0.11$ \\
\hline & $\mathrm{He}$ & $0.358 \pm 0.11$ & $0.327 \pm 0.10$ & $0.290 \pm 0.11$ & $0.375 \pm 0.08$ \\
\hline & $\mathrm{F}$ & $0.143 \pm 0.02$ & $0.106 \pm 0.03$ & $0.177 \pm 0.03$ & $-0.01 \pm 0.03$ \\
\hline & $\mathrm{X}^{2 \text { het }}$ & $95.82 * *(6)$ & $9.20(6)$ & $33.04 * *(4)$ & $39.77 * *(5)$ \\
\hline
\end{tabular}

- = F not calculated; $* * \mathrm{P}<0.01 ; * \mathrm{P}<0.05$; d.f. $=$ the numbers within parentheses.

Table IV - Analysis of intra- and interpopulation genetic structure by the Wright F-statistic in natural populations of Anopheles darlingi.

\begin{tabular}{lccc|}
\hline Locus & $\mathrm{F}_{\text {is }}$ & $\mathrm{F}_{\text {it }}$ & $\mathrm{F}_{\text {st }}$ \\
\hline EST2 & 0.106 & 0.117 & 0.013 \\
EST5 & -0.001 & 0.022 & 0.023 \\
IDH1 & -0.017 & 0.034 & 0.050 \\
ODH1 & 0.113 & 0.150 & 0.041 \\
AO1 & 0.659 & 0.663 & 0.070 \\
PGM & 0.198 & 0.221 & 0.029 \\
Mean & 0.083 & 0.107 & 0.026 \\
\hline
\end{tabular}

$\mathrm{F}_{\mathrm{is}}$ and $\mathrm{F}_{\mathrm{it}}$ are the $\mathrm{F}$ values (fixation index) of the individuals in the subpopulations and total population, respectively. $\mathrm{F}_{\mathrm{st}}$ is the degree of differentiation of the subpopulations in relation to the maximum possible differentiation in complete fixation.

Table $\mathbf{V}$ - Matrix of genetic distance and similarity among the four Anopheles darlingi populations.

\begin{tabular}{|lcccc|}
\hline Population & 1 & 2 & 3 & 4 \\
\hline 1 Ariquemes & $* * * * *$ & 0.012 & 0.010 & 0.024 \\
$\begin{array}{l}\text { 2 Porto Velho/ } \\
\text { Samuel }\end{array}$ & 0.988 & $* * * * *$ & 0.011 & 0.019 \\
$\begin{array}{l}\text { 3 Cachoeira } \\
\quad \text { Porteira }\end{array}$ & 0.990 & 0.989 & $* * * * *$ & 0.012 \\
4 Manaus & 0.976 & 0.981 & 0.989 & $* * * * *$ \\
\hline
\end{tabular}

The values above the diagonal correspond to unbiased genetic distance and those below the diagonal correspond to unbiased genetic identity (Nei, 1978).
Thus, we observed that gene frequency variability had an intrapopulational origin, and allele origin did not have much of an effect on the probability of sampling two different alleles in the set of populations.

Genetic distance and similarity data indicate that the four populations studied are genetically similar (Table V). The Ariquemes population is the closest to the Manaus population. Nevertheless, Ariquemes, Cachoeira Porteira and Porto Velho/Samuel have more in common genetically with each other than with Manaus (Figure II). The Manaus population is alone in a separate cluster.

\section{DISCUSSION AND CONCLUSIONS}

\section{Levels of genetic variability}

Allele frequency was not uniform for the different loci. Of the 19 loci analyzed, six presented variation. The observed deviation from genetic equilibrium was due in part to a larger number of observed than expected homozygotes, except for locus EST2 in the Manaus population.

Crouau-Roy (1988) pointed out that many studies have shown significant levels of heterozygote deficiency in natural populations, but usually these deficiencies are observed at some allozymic loci and/or only in some populations which have other loci in equilibrium. It has also been observed that different loci do not present the same 


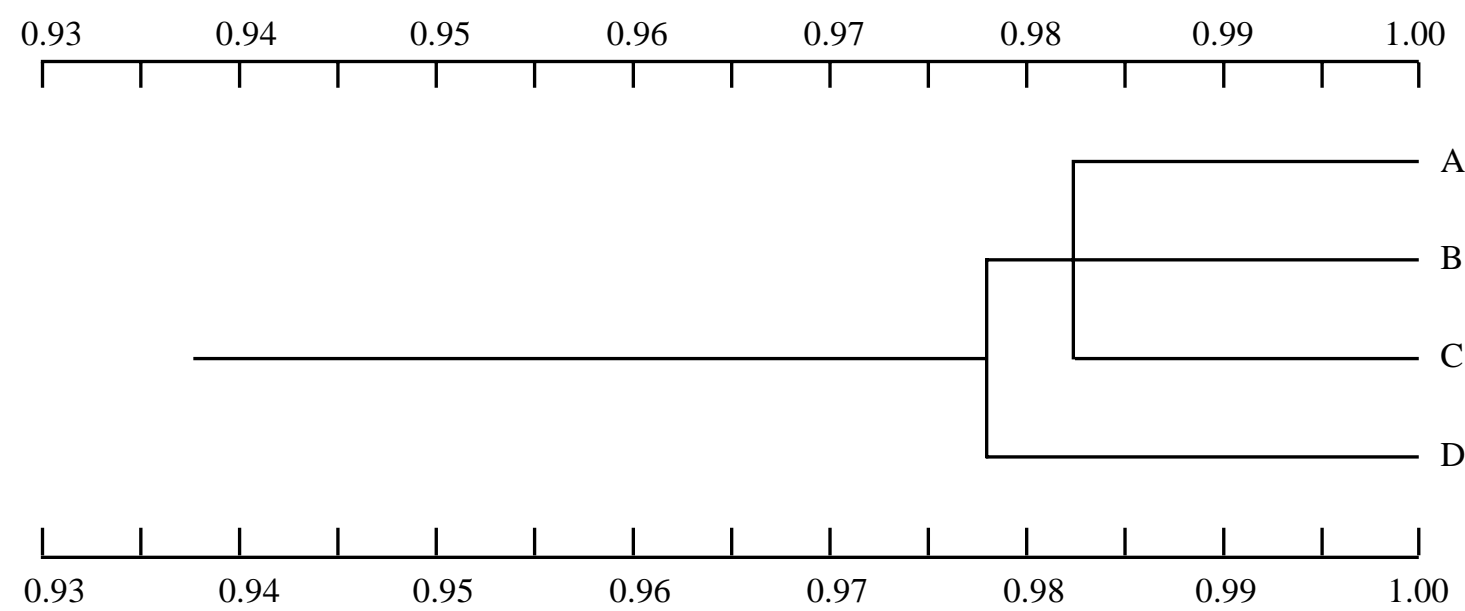

Figure 2 - Dendrogram resulting from grouping populations on the basis of genetic similarity by the unweighted pairing group method with arithmetic mean (UPGMA), determined by Nei (1978). A, Ariquemes; B, Cachoeira Porteira; C, Porto Velho/Samuel, and D, Manaus.

heterozygote deficiency. These observations have been frequently made in mosquitoes (Santos et al., 1985; Van Driel et al., 1987; Hii et al., 1991) and other insects (Sturgeon and Mitton, 1986: Crouau-Roy, 1988). These deficiencies were attributed by these investigators to differential genotype selection, inbreeding, null alleles, founder effect (bottleneck) and even the population structure itself. The same results were observed by Scarpassa (1988) in a natural population of $A$. nuneztovari from Tucuruí for three nonspecific esterase loci. The author attributed these results to ecological alterations introduced into the area which probably affected the genotype frequencies, with different adaptive values for homozygote classes.

In the case of null alleles for locus $O D H I$ of Porto Velho/Samuel population, it can be seen that the locus is in Hardy-Weinberg equilibrium. The occurrence of null alleles was observed in loci $A$ and $B$ of EST-C of $A$. punctipennis (Narang and Kitzmiller, 1971) and in the aldehyde oxidase of A. nuneztovari (Narang et al., 1979).

On the basis of the data presented, though the alleles had different frequencies among populations, the loci analyzed showed a certain homogeneity, with no detection of diagnostic loci for the various populations.

The proportion of polymorphic loci in the 19 loci analyzed in A. darlingi indicates a high level of polymorphism even though the number of alleles per locus showed small variation. Narang et al. (1979) also found a high level of polymorphism $(\mathrm{P}=0.632)$ for a population of $A$. darlingi from BR-174 (Manaus-Boa Vista). A relatively high degree of polymorphism has been also described in A. quadrimaculatus by Narang et al. (1989) in 50\% of the 33 loci analyzed. However, Van Driel et al. (1987) found in strains of A. stephensi from Pakistan that only six loci were polymorphic of the 16 loci analyzed. This species also showed lower observed heterozygosity as compared with $A$. darlingi $(\mathrm{Ho}=0.065$ to $0.086 / 0.236$ to 0.432 ). For 21 populations of different and incipient species of Anoph- eles, Cianchi et al. (1985) detected a wider range of both polymorphism and expected heterozygosity $(0.31 \leq \mathrm{P} \leq$ $0.78 ; 0.09 \leq \mathrm{He} \leq 0.24)$. The large scope of genetic variability in Anopheles species has been closely related to the very structure of the population, such as differential mating, mutation, selection, and genetic drift.

Considering the values observed for the A. darlingi population studied, there was high heterozygosity with levels close to those for the genus Culex $(0.290 \leq \mathrm{He} \leq$ $0.375)$. The same is true for polymorphism $(0.526 \leq \mathrm{P} \leq$ $0.631)$. $\mathrm{H}$ and $\mathrm{P}$ values obtained in the present study contrast with those reported by Lanzaro et al. (1990) for the A. quadrimaculatus complex in which heterozygosity was much lower $(0.10 \leq \mathrm{H} \leq 0.18)$. However, polymorphism showed a greater amplitude of variation $(0.32 \leq \mathrm{P} \leq 0.60)$.

\section{Genetic structure and population differentiation}

The disequilibrium resulting from excess homozygotes was observed in strains of A. stephensi (Van Driel et al., 1987), in which $\mathrm{F}_{\text {is }}$ values were higher than $\mathrm{F}_{\text {st }}$ values for most of the loci analyzed. Mean fixation among the different loci was low $\left(\mathrm{F}_{\text {it }}=0.107\right)$. However, locus $G p d h$ of $A$. stephensi and locus $A O 1$ of $A$. darlingi had high fixation indexes $\left(\mathrm{F}_{\mathrm{it}}=0.831\right.$ and 0.663 , respectively). The loci, especially $G p d h$ and $A 01$, did not make an equal contribution in either species. For $A$. darlingi, the fixation index indicated the occurrence of some type of isolation in most of the loci analyzed, which interferred with random mating within each population.

Based on fixation index data, variability of allele frequencies in A. darlingi populations is judged to be of intrapopulation origin, resulting from differentiation within these populations. This differentiation was produced by excess homozygotes within each locus and was more relevant within than between populations. However, elevated genetic divergence between populations of $\mathrm{C}$ species of 
A. quadrimaculatus (Narang et al., 1990) was observed, as indicated by the $\mathrm{F}_{\mathrm{st}}$ value of 0.219 . Genetic divergence between populations can be observed when a certain degree of reproductive isolation has already become established in the populations, as described by Narang et al. (1990).

The genetic distance and similarity between the four A. darlingi populations indicate that these populations are genetically similar $(0.976 \leq \mathrm{I} \leq 0.990)$ although they are geographically isolated. The genetic distance of these populations was very small $(0.010 \leq \mathrm{D} \leq 0.024)$, with Ariquemes showing the smallest genetic distance (0.010) compared to Cachoeira Porteira. However, this difference was not significant, so that Ariquemes, Cachoeira Porteira and Porto Velho/Samuel were grouped into the same cluster of the dendrogram.

Comparing these data with those for other mosquito species shows that genetic similarity and distance are similar, except in interspecific cases. For example, for species of the A. marshalli complex, isoenzyme analysis showed little divergence, with a genetic similarity index of 0.803-0.972 (Lambert, 1983). These values are similar to some pairs of cryptic species in which the genetic distances were $\mathrm{D}=0.13$ between $A$. gambiae Giles and $A$. arabiensis Patton; $\mathrm{D}=0.23$ between $A$. melanoon Hackett and $A$. maculipennis Meigen, and $\mathrm{D}=0.17$ between species A and B of A. stephensi strains (Van Driel et al., 1987). These results are similar to the values obtained for the four populations of $A$. darlingi, although with a lower amplitude of variation (0.010-0.024). These data may be interpreted on the basis of the genetic structure of the populations themselves, in which matings may occur with preferential crosses. Thus, considering the present data as a whole, we note that the populations presented greater intrapopulational than interpopulational differentiation in a process that has extended to four Amazonian populations studied. Datas on chromosomal variation in different samples from Amazonia did not indicate geographically differentiated populations. Samples from the central region of Amazon Basin did, however, present high polymorphism in relation to the marginal populations, which were mainly monomorphic (Tadei and Santos, 1982; Tadei et al., 1982; Tadei, 1986).

\section{ACKNOWLEDGMENTS}

The authors are grateful to Juracy de Freitas Maia for technical assistance. This research was supported in part by CNPq/ELETRONORTE. Publication supported by FAPESP.

\section{RESUMO}

Amostras de populações naturais de Anopheles darlingi foram analisadas para 19 locos, dos quais 12 apresentaram variação, com uma proporção de locos polimórficos de $68,40 \%$. A população de Ariquemes mostrou maior variabilidade, com maior número de alelos por loco $(2,26 \pm 0,08)$ e maior polimorfismo $(\mathrm{P}=63,15)$.
Levando-se em conta os níveis de heterozigosidade intraloco observados e esperados, os maiores valores foram observados na população de Manaus (Ho $=0,432 \pm 0,11 ; \mathrm{He}=0,375 \pm 0,08)$ e os menores na população de Cachoeira Porteira (Ho $=0,236 \pm$ 0,$09 ; \mathrm{He}=0,290 \pm 0,11$ ). Quando analisados pelas estatísticas $\mathrm{F}$ de Wright, os resultados mostraram desequilíbrio decorrente de excesso de homozigotos, conforme mostram os valores de $\mathrm{F}_{\text {is }}>$ $\mathrm{F}_{\mathrm{st}}(0,083>0,026)$, denotando uma certa diferenciação intrapopulacional. As quatro populações estudadas foram semelhantes geneticamente, conforme indicam os valores de distância e similaridade. As variações cromossômicas de populações da Amazônia não indicaram diferenciação geográfica, e na região central da bacia amazônica, estas foram altamente polimórficas em relação às marginais, que foram predominantemente monomórficas.

\section{REFERENCES}

Cabello, P.H. and Krieger, H. (1997). Genioc. Sistema para Análises de Dados de Genética. FIOCRUZ, Rio de Janeiro.

Cianchi, R., Urbanelli, S., Villani, F., Sabatini, A. and Bullini, L. (1985). Electrophoretic studies in mosquitoes. Recent advances. Parassitologia 27: 157-167.

Crouau-Roy, B. (1988). Genetic structure of cave-dwelling beetle populations: significant deficiencies of heterozygotes. Heredity 60: 321327.

Harbach, R.E., Roberts, D.R. and Manguin, S. (1993). Variation in the hindtarsal markings of Anopheles darlingi (Diptera: Culicidae) in Belize. Mosq. Syst. 25: 192-197.

Hii, J.L.K., Chew, M., Sang, V.Y., Munstermann, L.E., Tan, S.G., Panyim, S. and Yasothornsrikul, S. (1991). Population genetic analysis of host seeking and resting behaviors in the malaria vector, Anopheles balabacensis (Diptera: Culicidae). J. Med. Entomol. 28: 675684.

Kreutzer, R.D., Kitzmiller, J.B. and Ferreira, E. (1972). Inversion polymorphism in the salivary gland chromosomes of Anopheles darlingi. Mosq. News 32: 555-556.

Lambert, M.D. (1983). A population genetical study of the African mosquito Anopheles marshallii (Theoband). Evolution 37: 484-495.

Lanzaro, G.C., Narang, S.K. and Seawright, J.A. (1990). Speciation in an Anopheline (Diptera: Culicidae) mosquito: Enzyme polymorphism and the genetic structure of populations. Ann. Ent. Soc. Am. 83: 578585 .

Lima, L.M.K.S. and Contel, E.P.B. (1990). Electrophoretic analysis of 12 proteins in natural populations of Spodoptera frugiperda (Lepidoptera: Noctuidae). Rev. Bras. Genet. 13: 711-729.

Narang, G., and Kitzmiller, J.B. (1971). Esterase polymorphism in a natural population of A. punctipennis. II. Analysis of the Est-C system. Can. J. Genet. Cytol. 13: 771-776.

Narang, S., Santos, J.M.M., Garcia, J.C., Cristakou, H.D. and Narang, N. (1979). Genética de populações de anofelinos IV. Estudos eletroforéticos das populações naturais de Anopheles nuneztovari e Anopheles darlingi. Correlação genética entre espécies. Acta Amazonica 9: 529-542.

Narang, S.K., Kaiser, P.E. and Seawright, J.A. (1989). Dichotomus electrophoretic taxonomic key for identification of sibling species A, B and $\mathrm{C}$ of the Anopheles quadrimaculatus complex (Diptera: Culicidae). J. Med. Ent. 26: 94-99.

Narang, S.K., Seawright, J.A. and Kaiser, P.E. (1990). Evidence for microgeographic genetic subdivision of Anopheles quadrimaculatus species C. J. Am. Mosq. Control Assoc. 6: 179-187.

Nei, M. (1978). Estimation of average heterozygosity and genetic distance from a small number of individuals. Genetics 89: 583-590.

Rosa-Freitas, M.G., Broomfield, G., Priestman, A., Milligan, P.J.M., Momen, H. and Molyneux, D.H. (1992). Cuticular hydrocarbons, isoenzymes and behavior of three populations of Anopheles darlingi from Brazil. J. Am. Mosq. Control Assoc. 8: 357-366.

Rosa-Freitas, M.G., Conn, J., Mitchell, S.E., Cockburn, A.F., Seawright, J.A. and Momen, H. (1995). Mitochondrial DNA and morphologi- 
cal analyses of Anopheles darlingi populations from Brazil (Diptera: Culicidae). Mosq. Syst. 27: 78-99.

Santos, J.M.M., Contel, E.P.B. and Kerr, W.E. (1981). Biologia de Anofelinos amazônicos. 1. Ciclo biológico, postura e estádios larvais de Anopheles darlingi Root, 1926 (Diptera: Culicidae) da Rodovia Manaus/Boa Vista. Acta Amazonica 11: 789-797.

Santos, J.M.M., Contel, E.P.B. and Kerr, W.E. (1985). Biology of Amazonian mosquitoes. III. Esterase isozymes in Anopheles darlingi. Acta Amazonica 15: 167-177.

Santos, J.M.M., Tadei, W.P. and Contel, E.P.B. (1996). Electrophoretic analysis of 11 enzymes in natural populations of Anopheles (N.) darlingi Root, 1926 (Diptera: Culicidae) in the Amazon region. Acta Amazonica 26: 97-114.

Scarpassa, V.M. (1988). Estudo do ciclo biológico e de isoenzimas na ontogênese de Anopheles (Nyssorrhynchus) nuñez-tovari Gabaldon, 1940 (Diptera: Culicidae). Master's thesis, INPA/FUA, Manaus.

Steiner, W.W.M. and Joslyn, D.J. (1979). Electrophoretic techniques for the genetic studies of mosquitoes. Mosq. News 39: 35-54.

Sturgeon, K.B. and Mitton, J.B. (1986). Allozyme and morphological differentiation of mountain pine beetles Dendroctonus pondersae
Hopkins (Coleoptera: Scolytidae) associated with host tree. Evolution 40: 290-302.

Swofford, D.L. and Selander, R.B. (1981). Biosys-1: A Fortran program for the comprehensive analysis of electrophoretic data in population genetics and systematics. J. Hered. 72: 281-283.

Tadei, W.P. (1986). Estudos em espécies de Anopheles. Desempenho e rumos da Genética no Brasil. Rev. Bras. Genét. IX (Anais): 221-223.

Tadei, W.P. and Santos, J.M.M. (1982). Biologia de anofelinos amazônicos. VII. Estudo da variação de freqüência das inversões cromossômicas de Anopheles darlingi Root (Diptera: Culicidae). Acta Amazonica 12: 759-785.

Tadei, W.P., Santos, J.M.M. and Rabbani, M.G. (1982). Biologia de anofelinos amazônicos. V. Polimorfismo cromossômico de Anopheles darlingi Root (Diptera: Culicidae). Acta Amazonica 12: 353 369.

Van Driel, J.W., Sluiters, J.F. and Van Der Kaay, H.J. (1987). Allozyme variation in Anopheles stephensi Liston from Pakistan (Diptera: $\mathrm{Cu}-$ licidae). Biochem. Genet. 25: 789-802.

(Received August 14, 1997) 
